\title{
Effect of geotextile and agrotextile covering on productivity and nutritional values in lettuce
}

\author{
Ivana Tosic $^{1^{*}}$, Milan Mirosavljevic ${ }^{2}$, Novo Przulj ${ }^{3}$, Vojislav Trkulja ${ }^{1}$, Dusica Pesevic $^{4}$, and Jelena Barbir ${ }^{5}$ \\ ${ }^{1}$ Agricultural Institute of Republic of Srpska, 78000 Banja Luka, RS, Bosnia and Herzegovina. \\ "Corresponding author (it.tosic@gmail.com). \\ ${ }^{2}$ Institute for Field and Vegetable Crops, 21000 Novi Sad, Serbia. \\ ${ }^{3}$ University of Banja Luka, Faculty of Agriculture, 78000 Banja Luka, RS, Bosnia and Herzegovina. \\ ${ }^{4}$ University of Banja Luka, Faculty of Natural Sciences and Mathematics, 78000 Banjaluka, RS, Bosnia and Herzegovina. \\ ${ }^{5}$ Hamburg University of Applied Sciences, Faculty of Life Sciences, 21033 Hamburg, Germany.
}

Received: 28 January 2019; Accepted: 11 June 2019; doi:10.4067/S0718-58392019000400523

\begin{abstract}
In order to optimize the lettuce (Lactuca sativa L.) production in greenhouses and to evaluate how a usage of mulching and covering plants with woven agrotextile affects its yields, $\mathrm{N}$ content, nitrate, $\mathrm{Zn}$ and vitamin $\mathrm{C}$ in lettuce leaves, a 2 -yr experiment was established. In the experiments, black and white plastic foils were used for mulching before planting, and woven agrotextile for plant covering after planting. The effect of each, as well as combination of them, on lettuce growth and productivity was evaluated. The experiment involved six treatments: control (without mulch), polyethylene black plastic mulch, polyethylene white plastic mulch, polyethylene black plastic mulch and woven agrotextile, polyethylene white plastic mulch and woven agrotextile, and woven agrotextile. In the first growing season the yield was $23 \%$ higher when polyethylene black plastic mulch was used compared to the control. In the second growing season the yield was $29 \%$ higher when polyethylene black plastic mulch was used compared to the control. Nitrogen content decreased $9 \%$ when the woven agrotextile was used compared to the control. Polyethylene black plastic mulch and polyethylene black plastic mulch with agrotextile reduced $\mathrm{Zn}$ content compared to the control. Vitamin C content increased $21 \%$ when woven agrotextile was used compared to the control. The overall effect of mulching and covering plants with woven agrotextile showed positive effect on lettuce production. The results obtained could assist lettuce growers in selecting most effective production technologies in order to achieve highest yield and nutritional value in this crop.
\end{abstract}

Key words: Lettuce, nitrate, nitrogen, plastic mulch, vitamin C, zinc, woven agrotextile.

\section{INTRODUCTION}

In South Eastern Europe countries, such as Bosnia and Herzegovina, open field production of lettuce (Lactuca sativa L.) was dominant until several years ago, when an increasing trend of growing lettuce in greenhouses started to substitute traditional growing. Greenhouse production is very intensive, which gives producers the advantage to rotate crops throughout the year (Niari et al., 2012; Tringovska et al., 2015). Due to the greenhouse production and availability of numerous high yielding cultivars that could be well grown from early spring until late summer, lettuce is available on markets almost throughout the year (Theurl et al., 2017).

The different plastic mulch colours and woven agrotextile for plant covering are used for improvement of vegetable production. Plastic mulch application is effective in increasing soil temperature, conserving soil moisture and yield increase (Kumar and Lal, 2012; Tosic et al., 2014). Woven agrotextile is made of natural fibres and is used as a protection of young seedling from cold and to increase yield (Manna et al., 2018). It is a challenge to find the most optimum mulching and woven agrotextile combination. Selection of the appropriate colour mulch in the lettuce production is important for achieving higher yields and better quality. In order to achieve high yield and better quality of vegetables, apart 
from adequate adjustment of various production technologies, it is necessary to select proper cultivars, since besides the variation in yield, there is significant genotypic difference in nutritional quality and antioxidant traits in lettuce (Rouphael et al., 2017).

Nitrogen is an important element for successful plant development. It is of primary importance because it has several important roles in metabolic and regulatory processes in plants. However, the rational use of $\mathrm{N}$ fertilizers is extremely important because the accumulation of nitrates in lettuce leaves depends on the applied amount of $\mathrm{N}$ fertilizer. Lettuce may contain considerable amounts of nitrate (Zhou et al., 2013; Iammarino et al., 2014). Since lettuce is used fresh for human consumption, exceeded nitrate concentrations in lettuce may cause health problems (Keszei et al., 2013). High concentrations of nitrate in vegetables have led the European Union to introduce the limits of nitrate concentration in lettuce in order to reduce the consumption of nitrate by consumers (Commission regulation Nr 1258/2011; European Union, 2011). Accumulation of nitrate in lettuce plants is complex, because it is affected by both genetic and environmental factors. Nitrate content in leaf lettuce depends on various production technologies (Aires et al., 2013), as well as genotype. In conventional production, there is a greater content of vitamins and antioxidants and a lower content of nitrates than in organic-grown vegetables (Sobieralski et al., 2013). Vitamin C has an important role in the human body by increasing the resistance of organism to viral and bacterial infections. It is considered an important indicator of lettuce quality (Cometti et al., 2011).

Lettuce is rich in minerals and vitamins and is therefore essential in human nutrition (White and Brown, 2010). Spinach and lettuce can accumulate heavy metals ( $\mathrm{Zn}, \mathrm{Mn}, \mathrm{Fe}$ and $\mathrm{Cu}$ ) in their tissues (Uwah et al., 2012). Zinc is an element essential for maintaining good health throughout life (Radwan and Salama, 2006). Lettuce is one of the plant species that easily absorbs metals. Because of the high amounts of metals in soil, product quality can be reduced due to accumulation of metals in plants (Polat et al., 2008). The main objective of this experiment was to examine the impact of mulching and covering plants with woven agrotextile on the content of $\mathrm{N}$, nitrate, $\mathrm{Zn}$ and vitamin $\mathrm{C}$ in lettuce leaves, as well as to evaluate their impact on the yield of different lettuce cultivars.

\section{MATERIALS AND METHODS}

\section{Experimental data}

The experiment was conducted in a greenhouse at the experimental field of the National Agricultural Institute of

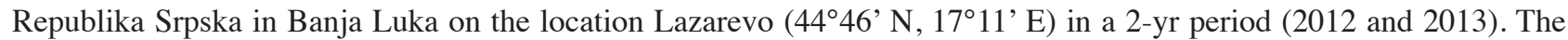
soil of the experimental field is classified as Fluvisol (IUSS Working Group WRB, 2015). Factorial experiment was set as randomized block design. Factor 1 was cultivar, with two levels ('Nizzi' and 'Devonia'), and factor 2 was the cover system, with six levels. The area of one plot was $5 \mathrm{~m}^{2}(1 \mathrm{~m} \times 5 \mathrm{~m})$. In each plot lettuce was planted in 4 rows, 16 plants per row. Lettuce seeds were sown in Styrofoam containers on the Tref substrate (Jiffy, Singapore) in the second half of January and seedlings were transplanted $40 \mathrm{~d}$ later, with a row spacing of $25 \mathrm{~cm}$ and the distance between plants of 30 $\mathrm{cm}$. In total, 3072 plants were used, of that 1536 'Nizzi' plants and another 1536 'Devonia' plants were organized in parallel distribution. Lettuce cropping cycle from planting to picking lasted $60 \mathrm{~d}$. In the experimental field, for mulching before planting the following were used: black plastic foil (thickness $22 \mu \mathrm{m}$ with 64 holes on $5 \mathrm{~m}^{2}$ ) and white plastic foil (thickness $30 \mu \mathrm{m}$ with 64 holes on $5 \mathrm{~m}^{2}$ ), and woven agrotextile (made of natural fibres, $25 \mathrm{~g} \mathrm{~m}^{-2}$ ) for plant covering after planting. The experiment involved six treatments: control (CO), polyethylene black plastic mulch (BPF), polyethylene white plastic mulch (WPF), a combination of polyethylene black plastic mulch and woven agrotextile (BPFWA), a combination of polyethylene white plastic mulch and woven agrotextile (WPFWA) and woven agrotextile (WA). Before the planting of lettuce, NPK fertilizer (7:20:30, Petrokemija, Kutina, Croatia) was applied to soil in the amount of 640 and $300 \mathrm{~kg} \mathrm{ha}^{-1}$ with calcium ammonium nitrate fertilizer (KAN 27\% N, Petrokemija, Kutina, Croatia). During the lettuce growth, the fertilization was performed twice, in the phase of intense rosette growing and before wrapping of lettuce head with Ferticare fertilizer (Yara Suomi Oy, Helsinki, Finland) with microelements (10:5:26) in the amount of $1 \mathrm{~g}$ per plant. Soil moisture was maintained at an optimum level by the system of drop by drop (four times during lettuce vegetation with $15 \mathrm{~L}$ water $\mathrm{m}^{-2}$. Soil moisture was maintained at an optimum level by the drip irrigation system where drop emitters brought water on demand during $5 \mathrm{~h}$ at rate of $3 \mathrm{~L} \mathrm{~m}^{-2} \mathrm{~h}^{-1}$ at a pressure of around $1 \mathrm{bar}$. In total four irrigations were applied, first immediately after transplanting seedlings and the next three every $15 \mathrm{~d}$. 
Harvest was carried out when lettuce plants reached the stage of technological maturity in the first week of May. Maturity is based on the number of leaves and head development. The mature lettuce heads had 36 leaves.

\section{Soil properties}

The standard properties of the soil in the greenhouse ( $\mathrm{pH}$ in $\mathrm{H}_{2} \mathrm{O}$, $\mathrm{pH}$ in $\mathrm{KCl}$, organic matter, $\mathrm{CaCO}_{3}, \mathrm{~N}^{-\mathrm{NO}_{3}}$ and $\mathrm{N}-\mathrm{NH}_{4}^{+}$) were analysed prior to the direct establishing of the experiment (Table 1). The soil in greenhouse in which the experiment was conducted had a high content of organic matter (6.0\%), and medium content of $\mathrm{CaCO}_{3}(5.2 \%)$. Soil reaction was determined in a suspension with $\mathrm{H}_{2} \mathrm{O}$ and $\mathrm{KCl}$ (ratio of 1:2.5), using a pH-meter (PHM240 pH/ion meter; Radiometer Analytical SAS, Lyon, France). The humus content in soil was determined by the colorimetric method, in the wet burned sample with $\mathrm{K}_{2} \mathrm{Cr}_{2} \mathrm{O}_{7}$ and concentrated $\mathrm{H}_{2} \mathrm{SO}_{4} \cdot \mathrm{CaCO}_{3}$ content was determined using Scheibler's calcimeter. The method Scheibler involves a determination of the carbonate content in the soil based on a volumetric method. The carbonates present in the sample were converted into $\mathrm{CO}_{2}$ by adding hydrochloric acid to the sample. The carbonate content is expressed as an equivalent calcium carbonate content. Nitrates and ammonia $\mathrm{N}\left(\mathrm{N}_{-} \mathrm{NO}_{3}{ }^{-}\right.$and $\left.\mathrm{N}_{-} \mathrm{NH}_{4}{ }^{+}\right)$were determined by

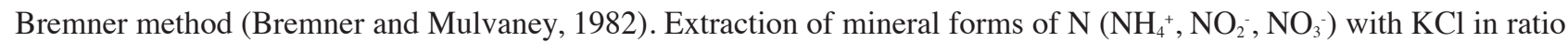
1:10, followed by double distillation.

\section{Greenhouse and soil temperature}

The mean, minimum and maximum air temperatures were measured by using digital thermometer (M288CTH, Mumbai, India) from March 2012 until May 2013 (Table 2).

Soil temperature was measured at $10 \mathrm{~cm}$ below the plastic mulch. The measurement of soil temperature was done using a digital soil thermometer (Rapitest; Luster Leaf Products, Woodstock, Illinois, USA).

\section{Chemical analysis of plant biomass}

The lettuce plants were harvested at technological maturity. During the harvest, 30 plants from each plot were weighed to determine the lettuce yield and from each plot four whole plants were randomly sampled for the chemical plant analysis.

The $\mathrm{N}$ content in leaves (N\%) was determined by Kjeldahl method (Horneck and Miller, 1998). The wet burning of plant material by concentrated $\mathrm{H}_{2} \mathrm{SO}_{4}+\mathrm{H}_{2} \mathrm{O}_{2}+450{ }^{\circ} \mathrm{C}-\mathrm{Kjeltec}$ analyzer (Foss Tecator 8400, Hilleroed, Denmark) and then distillation. The nitrate content in leaves was determined by the xylenol method. The extraction of nitrates by hot water, then distillation, and then colouring and reading of optical density on a UV/VIS spectrophotometer (6405; Jenway, Dunmow, Essex, England). The $\mathrm{Zn}$ content in leaves was determined by the preparation of plant material by wet burning with the mix of acids $\left(\mathrm{HNO}_{3}+\mathrm{HClO}_{4}+\mathrm{H}_{2} \mathrm{SO}_{4}\right)$, and then the $\mathrm{Zn}$ is converted to soluble salts and in the ionic form introduced as an aerosol into the atomic absorption spectrophotometer SP9 (Pye Unicam Ltd., Cambridge, England). The vitamin C content in leaves was determined by Tillman's titration method (Pijanowski et al., 1973). The leaf material was homogenized with $30 \mathrm{~cm}^{3} 2 \%$ oxalic acid and filtrated. The filtrate was charged with $1 \%$ oxalic acid (v/v) to a volume of $100 \mathrm{~cm}^{3}$. Then $10 \mathrm{~cm}^{3}$ of the extract were transferred to the Erlenmeyer bottle and then $40 \mathrm{~cm}^{3} 1 \%$ oxalic acid were added. The solution was titrated with 2,6-dichlorophenolindophenol.

Table 1. Soil characteristics of the experimental site.

\begin{tabular}{|c|c|c|c|c|c|c|}
\hline Depth & $\mathrm{pH}$ in $\mathrm{H}_{2} \mathrm{O}$ & $\mathrm{pH}$ in $\mathrm{KCl}$ & Organic matter & $\mathrm{CaCO}_{3}$ & $\mathrm{~N}-\mathrm{NO}_{3}$ & $\mathrm{~N}-\mathrm{NH}_{4}^{+}$ \\
\hline $\mathrm{cm}$ & & & $\%$ & 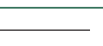 & 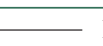 & 1 \\
\hline $0-30$ & 7.3 & 7.0 & 6.0 & 5.2 & 497.6 & 98.2 \\
\hline
\end{tabular}

Table 2. Mean monthly temperature.

\begin{tabular}{|c|c|c|c|c|c|c|}
\hline \multirow[b]{2}{*}{ Month } & \multicolumn{2}{|c|}{$\begin{array}{c}\text { Mean air } \\
\text { temperature }\end{array}$} & \multicolumn{2}{|c|}{$\begin{array}{l}\text { Mean maximum } \\
\text { temperature }\end{array}$} & \multicolumn{2}{|c|}{$\begin{array}{c}\text { Mean minimum } \\
\text { temperature }\end{array}$} \\
\hline & 2012 & 2013 & 2012 & 2013 & 2012 & 2013 \\
\hline & & & 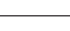 & & 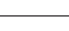 & 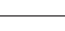 \\
\hline March & 12.2 & 14.7 & 17.4 & 20.5 & 5.3 & 7.3 \\
\hline April & 15.7 & 19.4 & 23.7 & 26.9 & 0.5 & 10.1 \\
\hline May & 20.4 & 22.6 & 26.2 & 29.1 & 4.2 & 10.8 \\
\hline
\end{tabular}




\section{Statistical analysis}

The obtained data were processed by InfoStat software (Grupo InfoStat, FCA, Universidad Nacional de Córdoba, Córdoba, Argentina). Two-factorial ANOVA was run for each year and the means were compared using Tukey’s test.

\section{RESULTS AND DISCUSSION}

\section{Effect of mulching and agrotextile on the lettuce yield}

Mean lettuce yield in 2012 and 2013 was 68.1 and 73.0 tha $^{-1}$, respectively. Significant differences between studied cultivars were observed in both growing seasons, where 'Devonia' tended to have significantly higher yield in both seasons. Based on the results of the analysis, soil was fertile and could provide optimal soil conditions for lettuce production (BoskovicRakocevic and Pavlovic, 2007). Growing conditions in 2013 were more favourable for lettuce production, with desirable temperature conditions (Table 2) resulting in higher yield in both cultivars. Results of yield in lettuce cultivars are shown in Table 3. Moreover, mulching treatment had significant effect on yield in both growing seasons. The lowest yield in both seasons of experiment was recorded in control treatments. The results obtained are consistent with previous studies, showing that soil mulching has a positive effect on plant growth and that it increases the vegetative mass and yield (Tosta et al., 2010). According to Franquera (2015) the use of different coloured mulches could enhance plant productivity and the quality of the products obtained from them. In both growing seasons, black plastic mulch produced the highest yield. In the second year of research, the cultivars were manifesting significant differences in the lettuce yield. The highest soil temperature was recorded below the black plastic mulch, and the lowest in WA treatment. This study showed that the colour of the plastic mulch positively influenced the yield of lettuce. Treatment with a black plastic mulch had a higher soil temperature than a white plastic mulch, as confirmed by the studies of Rangarajan and Ingall (2001). Ponjican and Bajkin (2008) state that the temperature difference due to the use of various materials for mulching and plant covering ranges in the interval of 6.22 to $12.71{ }^{\circ} \mathrm{C}$. In 'Devonia', in 2012 and 2013 , higher soil temperatures were registered in all treatments compared to 'Nizzi'. As a result of soil covering with black and white plastic mulch, a higher soil temperature was measured within the range of 4.2 to $6.82{ }^{\circ} \mathrm{C}$. The minimum daily average temperature in 2012 was measured in control treatment at $1.94{ }^{\circ} \mathrm{C}$, while in 2013 it was $3.48^{\circ} \mathrm{C}$. In 2013 , the maximum average daily soil temperature $\left(35.9^{\circ} \mathrm{C}\right)$ was recorded in black plastic mulch treatment with 'Devonia', when the highest lettuce yield was achieved.

\section{Effect of mulching and agrotextile on $\mathrm{N}$ content}

Mean $\mathrm{N}$ content varied between two growing seasons, and both cultivars had a lower $\mathrm{N}$ content in the first year of the experiment compared to the second year (Table 4).

There was nonsignificant difference between $\mathrm{N}$ content in the first growing season, while in the second growing season significant differences were noticed. The difference in the $\mathrm{N}$ content between studied cultivars in the second growing season indicated the presence of significant variation in $\mathrm{N}$ uptake potential of cultivars. Mean $\mathrm{N}$ content in 'Nizzi' was 38.9 (2012) and $40.3 \mathrm{~g} \mathrm{~kg}^{-1}$ (2013) and 39.5 (2012) and $45.5 \mathrm{~g} \mathrm{~kg}^{-1}$ (2013) in 'Devonia'. Therefore, it could be concluded

Table 3. Effect of mulching/woven agrotextile and cultivars on the lettuce yield during two growing seasons.

\begin{tabular}{|c|c|c|c|c|c|c|}
\hline \multirow[b]{2}{*}{ Treatments } & \multicolumn{3}{|c|}{2012} & \multicolumn{3}{|c|}{2013} \\
\hline & Nizzi & Devonia & Mean & Nizzi & Devonia & Mean \\
\hline & & & 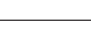 & 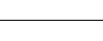 & & - \\
\hline $\mathrm{CO}$ & $57.9 \mathrm{~h}$ & $67.7 \mathrm{ef}$ & $62.8 \mathrm{E}$ & $59.9 \mathrm{i}$ & $70.2 \mathrm{f}$ & $65.0 \mathrm{D}$ \\
\hline BPF & $73.8 \mathrm{c}$ & $81.4 \mathrm{a}$ & $77.6 \mathrm{~A}$ & $79.7 \mathrm{c}$ & $88.7 \mathrm{a}$ & $84.2 \mathrm{~A}$ \\
\hline WPF & $66.6 \mathrm{f}$ & $76.0 \mathrm{~b}$ & 71.3B & $76.0 \mathrm{~d}$ & $82.6 \mathrm{~b}$ & 79.3B \\
\hline BPFWA & $62.4 \mathrm{~g}$ & $71.8 \mathrm{~d}$ & $67.1 \mathrm{C}$ & $64.1 \mathrm{~h}$ & $76.1 \mathrm{~d}$ & $70.1 \mathrm{C}$ \\
\hline WPFWA & $61.2 \mathrm{~g}$ & 68.1ef & $64.6 \mathrm{D}$ & $65.2 \mathrm{gh}$ & $74.0 \mathrm{e}$ & $69.6 \mathrm{C}$ \\
\hline WA & $61.3 \mathrm{~g}$ & $69.1 \mathrm{e}$ & $65.2 \mathrm{D}$ & $66.7 \mathrm{~g}$ & 73.0e & $69.8 \mathrm{C}$ \\
\hline
\end{tabular}

Different letters represent significant differences according to LSD test $(\mathrm{P}<0.05)$. Uppercase letters represent significant difference between treatments; lowercase letters represent significant difference between cultivars. CO: Control; BPF: polyethylene black plastic mulch; WPF: polyethylene white plastic mulch; BPFWA: polyethylene black plastic mulch and woven agrotextile; WPFWA: polyethylene white plastic mulch and woven agrotextile; WA: woven agrotextile. 
that 'Devonia' more efficiently accumulates $\mathrm{N}$ in the leaves than 'Nizzi'. Different authors have already reported existence of considerable variation in $\mathrm{N}$ content among different lettuce cultivars (Liu et al., 2014). In addition, $\mathrm{N}$ content varied in relation to treatments. In both growing seasons, in treatment BPF and treatment BPF in combination with WA, the highest level of $\mathrm{N}$ in leaves was registered, compared to the control treatment. Treatment BPF provides the highest productivity, but also the maximum values for $\mathrm{N}$ as well as its content in leaves.

\section{Effect of mulching and agrotextile on the nitrate content}

The results showed that nitrate content in plants varied between the growing seasons. On average in the second growing season, which was more suitable for lettuce cropping cycle, the plants had a higher nitrate content in their leaves. Furthermore, there were significant differences between examined cultivars in the nitrate content.

'Devonia' tends to have higher nitrate content than 'Nizzi' in both growing seasons. In the first growing season average nitrate content in leaf was the highest in treatment BPF, followed by combination of BPF and WA (Table 5). In the following season, application of black plastic mulch led to the highest nitrate content accumulation in leaf compared to the other treatments. On the other hand, the lowest nitrate content in both seasons was registered in treatment WA. Lower nitrate content was registered in spring in comparison to winter (Kosma et al., 2013). The treatments with plastic mulch and combined plastic mulch with woven agrotextile had higher nitrate contents in the second year, which was due to higher temperatures in that year (Table 2). The maximum values of nitrate content in our study are below the acceptable norms (4000 $\mathrm{mg} \mathrm{kg}^{-1}$ for lettuce grown in protected area) that are provided by the European Commission (Commission regulation Nr 1258/2011; European Union, 2011).

\section{Effect of mulching and agrotextile on the $\mathrm{Zn}$ content}

As result of different agroecological conditions, $\mathrm{Zn}$ content varied between the growing seasons (Table 6). Furthermore, total Zn content was significantly higher in 'Devonia' than in 'Nizzi' in each growing season.

Table 4. Effect of mulching/woven agrotextile and cultivars on the $\mathrm{N}$ content in lettuce during two growing seasons.

\begin{tabular}{|c|c|c|c|c|c|c|}
\hline \multirow[b]{2}{*}{ Treatments } & \multicolumn{3}{|c|}{2012} & \multicolumn{3}{|c|}{2013} \\
\hline & Nizzi & Devonia & Mean & Nizzi & Devonia & Mean \\
\hline & & & & & & \\
\hline $\mathrm{CO}$ & $36.9 \mathrm{~b}$ & $37.8 \mathrm{ab}$ & $37.3 \mathrm{C}$ & $37.0 \mathrm{f}$ & 40.3def & 38.7D \\
\hline BPF & $41.1 \mathrm{ab}$ & $42.0 \mathrm{a}$ & $41.5 \mathrm{~A}$ & $45.0 \mathrm{bc}$ & $50.2 \mathrm{a}$ & $47.6 \mathrm{~A}$ \\
\hline WPF & $39.6 a b$ & $38.6 \mathrm{ab}$ & 39.1ABC & 39.6def & $42.3 \mathrm{cde}$ & $41.0 \mathrm{CD}$ \\
\hline BPFWA & $40.0 \mathrm{ab}$ & $40.3 \mathrm{ab}$ & $40.2 \mathrm{AB}$ & $38.9 \mathrm{ef}$ & $50.3 \mathrm{a}$ & $44.6 \mathrm{~B}$ \\
\hline WPFWA & $36.9 \mathrm{~b}$ & $38.4 \mathrm{ab}$ & $37.7 \mathrm{BC}$ & 39.3def & $46.9 \mathrm{ab}$ & $43.2 \mathrm{BC}$ \\
\hline WA & $38.6 \mathrm{ab}$ & $39.7 \mathrm{ab}$ & $39.2 \mathrm{ABC}$ & $41.7 \mathrm{cde}$ & $43.0 \mathrm{Bcd}$ & $42.3 \mathrm{BC}$ \\
\hline
\end{tabular}

Different letters represent significant differences according to LSD test $(\mathrm{P}<0.05)$. Uppercase letters represent significant difference between treatments; lowercase letters represent significant difference between cultivars. CO: Control; BPF: polyethylene black plastic mulch; WPF: polyethylene white plastic mulch; BPFWA: polyethylene black plastic mulch and woven agrotextile; WPFWA: polyethylene white plastic mulch and woven agrotextile; WA: woven agrotextile.

Table 5. Effect of mulching/woven agrotextile and cultivars on the nitrate content in lettuce during two growing seasons.

\begin{tabular}{|c|c|c|c|c|c|c|}
\hline \multirow[b]{2}{*}{ Treatments } & \multicolumn{3}{|c|}{2012} & \multicolumn{3}{|c|}{2013} \\
\hline & Nizzi & Devonia & Mean & Nizzi & Devonia & Mean \\
\hline & & & & $s^{-1}-$ & & - \\
\hline $\mathrm{CO}$ & $2136.0 \mathrm{~g}$ & 2298.0f & $2217.0 \mathrm{E}$ & $2267.0 \mathrm{Gh}$ & $2664.0 \mathrm{e}$ & $2466.0 \mathrm{E}$ \\
\hline BPF & $3183.0 \mathrm{a}$ & $3035.0 \mathrm{~b}$ & $3109.0 \mathrm{~A}$ & $3444.0 \mathrm{a}$ & $3299.0 \mathrm{~b}$ & $3372.0 \mathrm{~A}$ \\
\hline WPF & $2495.0 \mathrm{e}$ & $2716.0 \mathrm{c}$ & $2606.0 \mathrm{C}$ & $2610.0 \mathrm{e}$ & $2898.0 \mathrm{c}$ & $2754.0 \mathrm{C}$ \\
\hline BPFWA & $2596.0 \mathrm{~d}$ & $2970.0 \mathrm{~b}$ & $2783.0 \mathrm{~B}$ & $2696.0 \mathrm{de}$ & $3299.0 \mathrm{~b}$ & $2998.0 \mathrm{~B}$ \\
\hline WPFWA & $2300.0 \mathrm{f}$ & $2592.0 \mathrm{~d}$ & $2446.0 \mathrm{D}$ & 2390.0f & $2806.0 \mathrm{~cd}$ & $2598.0 \mathrm{D}$ \\
\hline WA & $1978.0 \mathrm{~h}$ & $2084.0 \mathrm{~g}$ & $2031.0 \mathrm{~F}$ & $2175.0 \mathrm{~h}$ & 2308.0fg & $2242.0 \mathrm{~F}$ \\
\hline
\end{tabular}

Different letters represent significant differences according to LSD test $(\mathrm{P}<0.05)$. Uppercase letters represent significant difference between treatments; lowercase letters represent significant difference between cultivars. CO: Control; BPF: polyethylene black plastic mulch; WPF: polyethylene white plastic mulch; BPFWA: polyethylene black plastic mulch and woven agrotextile; WPFWA: polyethylene white plastic mulch and woven agrotextile; WA: woven agrotextile. 
The total Zn content in lettuce leaves was significantly influenced by the soil mulching in 2012 and 2013 growing seasons. Across genotype, $\mathrm{Zn}$ content in lettuce leaves varied between 56.0 and $65.0 \mathrm{mg} \mathrm{kg}^{-1}$ in 2012 and between 49.0 and $68.0 \mathrm{mg}$ $\mathrm{kg}^{-1}$ in 2013. According to Adu et al. (2012) the $\mathrm{Zn}$ content in leaves was $0.062 \pm 0.047 \mathrm{mg} \mathrm{kg}^{-1}$. Treatment BPFWA and the combination of BPFWA and WA enabled higher accumulation of $\mathrm{Zn}$ in lettuce leaves in both growing seasons. Treatment BPF and combination of BPF and WA in 2012 and treatment BPFWA in 2013 resulted in the lowest $\mathrm{Zn}$ content in lettuce leaves. Zinc content in all treatments is lower than the safety limit prescribed by FAO/WHO (2001) of $99.40 \mathrm{mg} \mathrm{kg}^{-1}$. Also, Tosic et al. (2012) pointed out that the soil mulching with black plastic mulch significantly reduced the $\mathrm{Zn}$ content in lettuce leaves. The $\mathrm{Zn}$ content in lettuce ranged from 42.0 to $91.0 \mathrm{mg} \mathrm{kg}^{-1}$ fresh weight (Meagy et al., 2016). The $\mathrm{Zn}$ content in treatments with woven agrotextile in combination with plastic mulch was significantly higher than in mulching treatments. The occurrence of $\mathrm{Zn}$ toxicity in humans is unlikely even when taking a rather high amount of $\mathrm{Zn}$ in lettuce leaves.

\section{Effect of mulching and agrotextile on the vitamin $\mathrm{C}$ content}

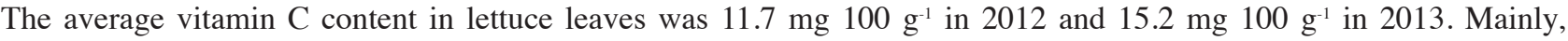
'Devonia' had higher content of vitamin C than 'Nizzi' (Table 7). Moreover, mulching with plastic foil had significant influence on vitamin $\mathrm{C}$ content in lettuce leaves.

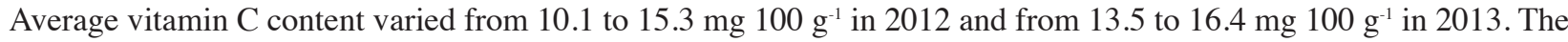
black plastic mulch absorbs sunlight, which increases soil temperature and reduces the content of vitamin C. Vitamin C is a significant factor in the human diet and the strongest antioxidant among vitamins. Vitamin $\mathrm{C}$ has distinct antioxidant characteristics and is a major antioxidant agent involved in removal of free radicals, together with mineral $\mathrm{Zn}$. The level of vitamin $\mathrm{C}$ was found to depend on the soil mulching, plant coverage and cultivar. All treatments had lower vitamin $\mathrm{C}$ content in the first year of the study than in the second year. Lettuce is not rich in vitamin $\mathrm{C}$, but the advantage of this vegetable is that it is consumed fresh, so the vitamin $\mathrm{C}$ is fully exploited.

Table 6. Effect of mulching/woven agrotextile and cultivars on the $\mathrm{Zn}$ content in lettuce during two growing seasons.

\begin{tabular}{|c|c|c|c|c|c|c|}
\hline \multirow[b]{2}{*}{ Treatments } & \multicolumn{3}{|c|}{2012} & \multicolumn{3}{|c|}{2013} \\
\hline & Nizzi & Devonia & Mean & Nizzi & Devonia & Mean \\
\hline $\mathrm{CO}$ & $58.0 \mathrm{cde}$ & 60.0 bcde & $59.0 \mathrm{~B}$ & $47.0 \mathrm{~g}$ & $59.0 \mathrm{~cd}$ & $53.0 \mathrm{C}$ \\
\hline $\mathrm{BPF}$ & $57.0 \mathrm{de}$ & $59.0 \mathrm{cde}$ & $58.0 \mathrm{~B}$ & $50.0 \mathrm{fg}$ & $60.0 \mathrm{c}$ & $49.0 \mathrm{D}$ \\
\hline WPF & $64.0 \mathrm{abc}$ & $67.0 \mathrm{a}$ & $65.0 \mathrm{~A}$ & 51.0efg & $62.0 \mathrm{bc}$ & $62.0 \mathrm{~B}$ \\
\hline BPFWA & $59.0 \mathrm{cde}$ & $57.0 \mathrm{de}$ & $58.0 \mathrm{~B}$ & $54.0 \mathrm{ef}$ & $63.0 \mathrm{bc}$ & $55.0 \mathrm{C}$ \\
\hline WPFWA & 63.0abcd & $66.0 \mathrm{ab}$ & $64.0 \mathrm{~A}$ & $55.0 \mathrm{de}$ & $65.0 \mathrm{~b}$ & $68.0 \mathrm{~A}$ \\
\hline WA & $55.0 \mathrm{e}$ & $58.0 \mathrm{cde}$ & $56.0 \mathrm{~B}$ & $55.0 \mathrm{de}$ & $70.0 \mathrm{a}$ & $61.0 \mathrm{~B}$ \\
\hline
\end{tabular}

Different letters represent significant differences according to LSD test $(\mathrm{P}<0.05)$. Uppercase letters represent significant difference between treatments; lowercase letters represent significant difference between cultivars. CO: Control; BPF: polyethylene black plastic mulch; WPF: polyethylene white plastic mulch; BPFWA: polyethylene black plastic mulch and woven agrotextile; WPFWA: polyethylene white plastic mulch and woven agrotextile; WA: woven agrotextile.

Table 7. Effect of mulching/woven agrotextile and cultivars on the vitamin $\mathbf{C}$ content in lettuce during two growing seasons.

\begin{tabular}{|c|c|c|c|c|c|c|}
\hline \multirow[b]{2}{*}{ Treatments } & \multicolumn{3}{|c|}{2012} & \multicolumn{3}{|c|}{2013} \\
\hline & Nizzi & Devonia & Mean & Nizzi & Devonia & Mean \\
\hline & & & 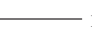 & -1 & & - \\
\hline $\mathrm{CO}$ & $9.9 \mathrm{f}$ & 10.3ef & $10.1 \mathrm{C}$ & $13.3 \mathrm{f}$ & $13.7 \mathrm{ef}$ & $13.5 \mathrm{D}$ \\
\hline BPF & $10.2 \mathrm{ef}$ & $11.2 \mathrm{de}$ & $10.7 \mathrm{C}$ & 14.1de & $15.0 \mathrm{c}$ & $14.6 \mathrm{C}$ \\
\hline WPF & $10.4 \mathrm{ef}$ & 10.6ef & $10.5 \mathrm{C}$ & $15.3 \mathrm{c}$ & $14.6 \mathrm{~cd}$ & $14.9 \mathrm{C}$ \\
\hline BPFWA & $10.7 \mathrm{ef}$ & $12.2 \mathrm{c}$ & $11.5 \mathrm{~B}$ & $16.9 \mathrm{~b}$ & $15.1 \mathrm{c}$ & $16.0 \mathrm{AB}$ \\
\hline WPFWA & $12.0 \mathrm{~cd}$ & $12.2 \mathrm{~cd}$ & $12.1 \mathrm{~B}$ & 14.1de & $17.7 \mathrm{a}$ & $15.9 \mathrm{~B}$ \\
\hline WA & $14.2 \mathrm{~b}$ & $16.4 \mathrm{a}$ & $15.3 \mathrm{~A}$ & $14.8 \mathrm{~cd}$ & $18.1 \mathrm{a}$ & $16.4 \mathrm{~A}$ \\
\hline
\end{tabular}

Different letters represent significant differences according to LSD test $(\mathrm{P}<0.05)$. Uppercase letters represent significant difference between treatments; lowercase letters represent significant difference between cultivars. CO: Control; BPF: polyethylene black plastic mulch; WPF: polyethylene white plastic mulch; BPFWA: polyethylene black plastic mulch and woven agrotextile; WPFWA: polyethylene white plastic mulch and woven agrotextile; WA: woven agrotextile. 


\section{CONCLUSIONS}

Based on the results of the study, it is evident that geotextile and agrotextile had a major impact on the most frequently examined parameters of lettuce. The results obtained emphasize importance of appropriate cultivars selection and application of adequate mulching for achievement of high yield and quality in lettuce. In treatment with polyethylene black plastic mulch the highest level of $\mathrm{N}$ in lettuce leaves was registered. The woven agrotextile treatment led to significant reduction of nitrate level in lettuce. The $\mathrm{Zn}$ content in treatments with woven agrotextile in combination with plastic mulches was significantly higher than in plastic mulches treatments. The polyethylene black plastic mulch produced the highest yield, but also a higher nitrate content. The treatment with woven agrotextile had a positive effect on the vitamin $\mathrm{C}$ content in lettuce.

\section{ACKNOWLEDGEMENTS}

This research was supported by the Ministry of Science and Technology of the Government of Republic of Srpska and the City of Banja Luka in Bosnia and Herzegovina, project Nr 02-330-355/11.

\section{REFERENCES}

Adu, A.A., Aderinola, O.J., and Kusemiju, V. 2012. Heavy metals concentration in Garden lettuce (Lactuca sativa L.) grown along Badagry expressway, Lagos, Nigeria. Transnational Journal of Science and Technology 2(7):115-130.

Aires, A., Carvalho, R., Rosa, E.A.S., and Saavedra, M.J. 2013. Effects of agriculture production systems on nitrate and nitrite accumulation on baby-leaf salads. Food Science and Nutrition 1(1):3-7. doi:10.1002/fsn3.1.

Boskovic-Rakocevic, L.J., and Pavlovic, P. 2007. Nitrogen fertilization influences on nitrate contents in spinach. Cereal Research Communications 35(2):289-292. doi:10.1556/CRC.35.2007.2.61.

Bremner, J.M., and Mulvaney, C.S. 1982. Salicylic acid-thiosulfate modification of Kjeldahl method to include nitrate and nitrite. In Page, A.L. (ed.) Methods of soil analysis. Part 2. Chemical and microbiological properties. $2^{\text {nd }}$ ed. Academic Press, New York, USA.

Cometti, N., Martins, M., Bremenkamp, C., and Nunes, A. 2011. Nitrate concentration in lettuce leaves depending on photosynthetic photon flux and nitrate concentration in the nutrient solution. Horticulture Brasil 29:548-553.

European Union. 2011. Commission regulation (EU) No 1258/2011 of 2 December 2011 amending Regulation (EC) No $1881 / 2006$ as regards maximum levels for nitrates infoodstuffs (Text with EEA relevance). Official Journal of the European Union L320/15, 3.12.2011. Available at https://eur-lex .europa.eu/legal-content/EN/TXT/PDF/?uri=OJ:L:2011:320:FULL\&from=EN .

IUSS Working Group WRB. 2015. World reference base for soil resources 2014, update 2015. International soil classification system for naming soils and creating legends for soil maps. World Soil Resources Reports Nr 106. 192 p. FAO, Rome, Italy. Available at http://www.fao.org/3/i3794en/I3794en.pdf.

FAO/WHO. 2001. Food additives and contaminants (ALINORM 01/12). Codex Alimentarius Commission. Joint FAO/WHO Food Standards Programme, Geneva, Switzerland.

Franquera, E. 2015. Effects of plastic mulch color on the total soluble solids, total sugars and chlorophyll content of lettuce (Lactuca sativa L.) International Journal of Research in Agriculture and Forestry 2(8):18-24.

Horneck, D.A., and Miller, R.O. 1998. Determination of total nitrogen in plant tissue. In Kalra, Y.P. (ed.) Handbook of reference methods for plant analysis. CRC Press, Boca Raton, Florida, USA.

Iammarino, M., Taranto, D.A., and Cristino, M. 2014. Monitoring of nitrites and nitrate levels in leafy vegetables (spinach and lettuce): a contribution to risk assessment. Journal Science of Food Agriculture 94:773-778. doi:10.1002/jsfa.6439.

Keszei, A.P., Schouten, L.J., Driessen, A.L., Huysentruyt, C.J., Keulemans, Y.C., Goldbohm, R.A., et al. 2013. Dietary N-nitroso compounds, endogenous nitrosation, and the risk of esophageal and gastric cancer subtypes in the Netherlands Cohort Study. American Journal of Clinical Nutrition 97:135-146. doi:10.3945/ajcn.112.043885.

Kosma, C., Triantafyllidis, V., Papasavas, A., Salahas, G., and Patakas, A. 2013. Yield and nutritional quality of greenhouse lettuce as affected by shading and cultivation season. Emirates Journal of Food Agriculture 25(12):974979. doi:10.9755/ejfa.v25i12.16738.

Kumar, S.D., and Lal, B.R. 2012. Effect of mulching on crop production under rainfed condition: A review. International Journal of Research in Chemistry and Environment 2:8-20.

Liu, C.W., Sung, Y., Chen, B.C., and Lai, H.Y. 2014. Effects of nitrogen fertilizers on the growth and nitrate content of lettuce (Lactuca sativa L.) International Journal of Environmental Research and Public Health 11(4):4427-4440. doi:10.3390/ijerph110404427. 
Manna, K., Kundu, M.C., Saha, B., and Ghosh, G.K. 2018. Effect of nonwoven jute agrotextile mulch on soil health and productivity of broccoli (Brassica oleracea L.) in lateritic soil. Environmental Monitoring and Assessment 190(82):1-10. doi:10.1007/s10661-017-6452-y.

Meagy, M.J., EL-Jaoual, T.E., and Allen, V.B. 2016. 66. Journal of Plant Nutrition 39:743-748. doi:10.1080/01904167.2015.1016173.

Niari, S.M., Bahri, M.H., and Rashidi, M. 2012. Chemical materials application and storage periods effects on vitamin C of ambient stored lettuce. Journal of Agriculture and Environmental Sciences 12:1081-1084.

Pijanowski, E., Mrozewski, S., Horubala, A., and Jarczik, A. 1973. Fruit and vegetables processing. p. 127-134. PWRiL, Warsaw, Poland.

Polat, E., Demir, H., and Onus, A.N. 2008. Comparison of some yield and quality criteria in organically and conventionallygrown lettuce. African Journal of Biotechnology 7:1235-1239. doi:10.5897/AJB07.649.

Ponjican, O., and Bajkin, A. 2008. The influence of soil cultivation and plant cover on T air in lettuce production. Journal Contemporary Agricultural Engineering 34(3):117-270.

Radwan, M.A., and Salama, A.K. 2006. Market basket survey for some heavy metals in Egyptian fruits and vegetables. Food Chemistry Toxicology 44:1273-1278. doi.org/10.1016/j.fct.2006.02.004.

Rangarajan, A., and Ingall, B. 2001. Mulch colour affects radicchio quality and yield. Horticulturae Science 36(7):1240-1243.

Rouphael, Y., Kyriacou, M.C., Vitaglione, P., Giordano, M., Pannico, A., Colantuono, A., et al. 2017. Genotypic variation in nutritional and antioxidant profile among iceberg lettuce cultivars. Acta Scientiarum Polonorum Hortorum Cultus 16(3):3745. doi:10.24326/asphc.2017.3.4.

Sobieralski, K., Siwulski, M., and Sas-Golak, I. 2013. Nutritive and health-promoting value of organic vegetables. Acta Scientiarum Polonorum 12(1):113-123.

Theurl, M.C., Hortenhuber, S.J., and Lindenthal, T. 2017. Unheated soil-grown winter vegetables in Austria: Greenhouse gas emission and socio-economic factors of diffusion potential. Journal of Cleaner Production 151:134-144.

Tosic, I., Ilin, Z., Maksimovic, I., and Pavlovic, S. 2014. The effect of plant mulching and covering on the lettuce yield and nitrate content (Lactuca sativa L.) African Journal of Agricultural Research 9(23):1774-7177. doi:10.5897/AJAR2012.856.

Tosic, I., Ilin, Z., Maksimovic, I., Bogdanovic, D., and Dardic, M. 2012. The effect of mulching and direct covering on content of some nutrient elements in lettuce. p. $429-431.47^{\text {th }}$ Croatian and $7^{\text {th }}$ International Symposium on Agriculture, Opatija, Croatia.

Tosta, P., Mendonca, V., Tosta, M., Machado, J.R., Tosta, J., and Medeiros, L. 2010. Utilização de coberturas de solo no cultivo de alface ‘Babá de Verão’ em Cassilândia (MS). Revista Brasileira de Ciências Agrárias 5(1):85-89.

Tringovska, I., Yankova, V., Markova, D., and Mihov, M. 2015. Effect of companion plants on tomato greenhouse production. Scientia Horticulturae 186:31-37. doi:10.1016/j.scienta.2015.02.016.

Uwah, E.I., Gimba, M.S.B., and Gwaski, P.A. 2012. Determination of Zn, Mn, Fe and Cu in spinach and lettuce cultivated in Potiskum, Yobe State, Nigeria. Journal of Agricultural Economics and Development 1:69-74.

White, P.J., and Brown, P.H. 2010. Plant nutrition for sustainable development and global health. Annals of Botany 105(7):10731080. doi:10.1093/aob/mcq085.

Zhou, W., Liu, W., and Yang, Q. 2013. Reducing nitrate content in lettuce by pre-harvest continuous light delivered by red and blue light-emitting diodes. Journal of Plant Nutrition 36(3):481-490. doi:10.1080/01904167.2012.748069. 